\title{
FORMULASI MASKER GEL PEEL OFF DARI EKSTRAK ETANOL UMBI BAWANG DAYAK (Eleutherinebulbosa (Mill.) Urb. Eleutherine americana Merr)
}

\author{
${ }^{1,2}$ Akademi Farmasi Yarsi Pontianak \\ Dian Kartikasari $^{* 1)}$, Reni Anggraini ${ }^{2)}$ \\ Jl. Panglima A'im no 2 Pontianak \\ Email: diankartikasari223@gmail.com
}

\section{INTISARI}

Umbi bawang dayak memiliki kadar antioksidan yang sangat tinggi. Penelitian ini bertujuan mendapatkan formula masker gel feel off ekstrak umbi bawang dayak yang menghasilkan pembentukan film yang baik berdasarkan hasil evaluasi fisik. Masker gel peel off dibuat dalam 3 formula dengan parameter perbedaan konsentrasi PVA. Formula 1 PVA $10 \%$, formula $212 \%$, formula 3 PVA 13\%. Proses pembuatan ekstrak dengan cara maserasi, kemudian dipekatkan dengan evaporator dan dibuat sediaan masker gel peel off dengan penambahan eksipien. Hasil uji organoleptis menunjukkan parameter aroma, warna dan tekstur tidak berbeda nyata antar formula. Hasil uji fisik menunjukkan formula 3 dengan PVA $13 \%$ menghasilkan masker gel peel off yang paling baik dibandingkan dengan formula 1 dan 2, dengan nilai viskositas $3,833 \mathrm{cps}$, pH 6, homogeny, waktu mongering < 15 menit dan uji daya sebar $5,815 \mathrm{~cm}$.

Kata kunci: bawang dayak, masker gel peel off, PVA.

\begin{abstract}
Bawang Dayak bulbs have a very high antioxidant content. This study aims to get the mask gel feel off formula the bawang Dayak bulb extract that results in good film formation based on the results of physical evaluation. The mask gel Peel off is made in 3 formulas with different parameters of PVA concentration. Formula 1 PVA $10 \%$, formula $212 \%$, formula 3 PVA $13 \%$. The process of preparing the extract by maceration, then concentrated with evaporator and made gel mask preparation with the addition of excipients. The results of organoleptic tests showed the parameters of aroma, color and texture were not significantly different between the formulas. Physical test results showed that formula 3 with PVA $13 \%$ yielded the best peel off gel mask compared with formula 1 and 2, with viscosity value $3,833 \mathrm{cps}, \mathrm{pH} 6$, homogeny, mongering time <15 min and spreading test $5,515 \mathrm{~cm}$.
\end{abstract}

Keywords: Bawang Dayak, mask gel peel off, PVA.

Corresponding author:

Dian kartikasari

Akademi Farmasi Yarsi Pontianak

JL. Panglima A'im No. 2 Pontianak

Email: diankartikasari223@gmail.com

\section{PENDAHULUAN}

Bawang Dayak memiliki nama lokal yang beragam seperti Bawang Tiwai, bawang Sabrang, bawang berlian, bawang lubak, teki sebrang atau bawang hantu. Bawang Dayak 
merupakan tanaman khas Kalimantan Tengah. Secara turun temurun bawang dayak sudah dipergunakan masyarakat lokal sebagai obat berbagai jenis penyakit berat maupun penyakit ringan seperti kanker payudara, membantu mengatasi penyakit diabetes melitus, menurunkan hipertensi, menurunkan kadar kolesterol, obat bisul, antitumor dan lainnya (Saptowalyono, 2007). Umbi bawang dayak memiliki kadar antioksidan yang sangat tinggi, yang berguna untuk melindungi selsel dari dampak radikal bebas yang merusak (Hidayah, dkk, 2015). Umbi bawang dayak juga sebagai antimikroba, beberapa mikroba yang dipublikasi dapat menyebabkan gangguan kulit antara lain Staphylococcus aureus dan kapang Tricophhyton rubrum (Siregar, 2002).

Bawang dayak mengandung senyawa-senyawa kimia seperti alkaloid, glikosid, flavonoid, fenolik, steroid, dan tannin yang merupakan sumber potensial untuk dikembangkan sebagai tanaman obat. Alkaloid memiliki fungsi sebagai antimikroba. Selain itu, alkaloid, glikosid, dan flavonoid juga memiliki fungsi sebagai hipoglikemik sedangkan tanin biasa digunakan sebagai obat sakit perut (Galingging, 2007). Flavonoid merupakan senyawa yang memiliki aktivitas antioksidan golongan flavonoid yang bersifat antioksidan meliputi flavon, flavonol, isoflavon, katekin, dan kalkon (Kumalaningsih, 2006).

Kulit merupakan lapisan pelindung tubuh dari paparan polusi lingkungan, terutama kuit wajah yang sering terpapar oleh sinar ultraviolet (UV) akibatnya dapat menimbulkan masalah kulit seperti keriput, penuaan, jerawat dan pori kulit yang membesar, sehingg merupaka hal yang penting untuk merawat kulit itu sendiri (Grace dkk., 2015).

Efek antioksidan dan antijerawat untuk perawatan kulit wajah akan lebih baik diformulasikan dalam bentuk topikal dibandingkan dengan oral karena zat aktif akan berinteraksi lebih lama dengan kulit wajah (Draelos \& Thaman, 2006). Kosmetik wajah dapat diperoleh dalam berbagai bentuk sediaan, salah satunya dalam bentuk masker wajah gel peel off (Vieira dkk., 2009). Masker wajah merupakan kosmetik perawatan kecantikan yang sangat popular untuk meningkatkan kualitas kulit (Yeom dkk., 2011).

Masker wajah peel off merupakan salah satu jenis masker wajah yang mempunyai keunggulan dalam penggunaanya yaitu dapat dengan mudah dilepas atau diangkat seperti membran elastis (Rahmawanty dkk., 2015). Masker wajah peel off dapat meningkatkan hidrasi pada kulit kemunkinan karena adanya oklusi (Velasco dkk., 2014). Penggunaan masker wajah peel off bermanfaat untuk memperbaiki serta merawat kulit wajah dari masalah keriput, penuaan, jerawat dan dapat juga digunakan untuk mengecilkan pori (Grace dkk., 2015). Selain itu, masker peel off juga dapat digunakan untuk membersihkan serta melembabkan kulit. Kosmetik wajah dalam bentuk masker peel off bermanfaat dalam merelaksasi otot-otot wajah, sebagai pembersih, penyegar, pelembab dan pelembut bagi kulit wajah (Vieira dkk., 2009).

Pembuatan kosmetik dari bahan alami lebih baik dari pada bahan sintesis. Bahan sintesis dapat menimbulkan efek samping bahkan dapat merusak bentuk alami dari kulit (Grace dkk., 2015). Masker wajah peel off diformulasikan dengan basis polivinil alkohol (PVA), setelah pengolesan dan pengeringan akan membentuk lapisan oklusif pada wajah (Vieira dkk., 2009). Zat aktif ditambahkan ke dalam formulasi untuk meningkatkan efek oklusi dan tensor. Formulasi tersebut mengandung bahan pelunak, pelembab, pengawet, surfaktan, pewangi dan zat aktif (Zague dkk., 2008). PVA berperan dalam memberikan efek peel off karena memiliki sifat adhesive sehingga dapat memebentuk lapisan film yang mudah dikelupas setelah kering (Brick dkk., 2014). Konsentrasi PVA merupakan faktor terpenting yang berpengaruh terhadap kinerja pembentukan film dalam masker wajah peel off (Beringhs dkk., 2013). Konsentrasi PVA dalam formulasi masker wajah gel peel off dapat berpengaruh terhadap pembentukan film saat pemnggunaan di wajah dan waktu pengeringan sediaan (Rahmawanty dkk., 2015; Barel dkk., 2009). Berdasarkan latar belakang tersebut, maka perlu dilakukan optimasi formulasi sediaan masker gel peel off untuk perawatan kulit wajah.

JIFFK Vol. 14, No. 1, JUNI 2018, Hal. 01 - 11 


\section{METODE PENELITIAN}

Bahan penelitian

Bahan yang digunakan dalam penelitian ini adalah umbi bawang dayak (Eleutherine americana Merr.), PVA, HPMC, Propilengikol, Metil paraben, propil paraben, ol. rosae, aquades, Alkohol 96\%.

\section{Alat Penelitian}

Peralatan yang digunakan dalam penelitian ini adalah timbangan analitik, batang pengaduk, pisau, beaker glass, kaca arloji, gelas ukur, mortir dan stemper, sendok stainless, kertas $\mathrm{pH}$, jangka sorong, kain flanel, kaca, oven, dan wadah sediaan, viskometer Brookfield tipe VT- 043, rotary evaporato rtipe RV 10 digital $\mathrm{V}$.

\section{JALANNYA PENELITIAN}

\section{Pengolahan Sampel}

Umbi bawang dayak yang sudah dikumpulkan disortasi basah untuk memisahkan bagian tanaman yang tidak diinginkan. Umbi bawang dayak di cuci menggunakan air mengalir hingga bersih, kemudian dilakukan perajangan pada umbi bawang dayak. Setelah itu diangin-anginkan dengan dijemur dibawah sinar matahari dengan ditutup kain hitam, kemudian dilakukan sortasi kering untuk memisahkan benda-benda asing yang tertinggal. Umbi bawang dayak yang telah dikeringkan dihaluskan hingga menjadi serbuk, selanjutnya dimaserasi dengan pelarut etanol $96 \%$, maserasi dilakukan selama $3 \times 24$ jam setiap 1 kali 24 jam pelarutnya diganti. Saring dengan kain flanel kemudian filtrat dikumpulkan dan dipekatkan dengan rotary evaporator sehingga didapat ekstrak kental

Tabel I. Formula masker gel peel off ekstrak etanol umbi bawang dayak

\begin{tabular}{lccc}
\multicolumn{1}{c}{ Bahan } & \multicolumn{3}{c}{ Formula (\%) } \\
\cline { 2 - 4 } & $\mathbf{1}$ & $\mathbf{2}$ & $\mathbf{3}$ \\
\hline Ekstrak umbi bawang Dayak & 4 & 4 & 4 \\
PVA & 10 & 12 & 13 \\
HPMC & 2 & 2 & 2 \\
Propilenglikol & 10 & 10 & 10 \\
Metil paraben & 0,02 & 0,02 & 0,02 \\
Propil paraben & 0,05 & 0,05 & 0,05 \\
Ol rosae & $\mathrm{qs}$ & $\mathrm{qs}$ & $\mathrm{qs}$ \\
Aquadest & $\mathrm{Ad} \mathrm{100}$ & $\mathrm{Ad} \mathrm{100}$ & $\mathrm{Ad} \mathrm{100}$ \\
\hline
\end{tabular}

2. Prosedur Pembuatan

Masing-masing bahan ditimbang dan alat disiapkan. PVA dikembangkan dalam aquadest panas hingga mengembang sempurna didalam cawan penguapkemudian diaduk. Dikembangkan pula HPMC dalam aquadest panas hingga mengembang sempurna, kemudian PVA dan HPMC di gerus hingga homogen tambahkan propil paraben yang telah dilarutkan kemudian masukkan metil paraben dan propilenglikol gerus sampai homogen, setalah itu ditambahkan sisa aquadest gerus hingga homogen, tambahkan ol. rosae, kemudian ditambahkan ekstrak etanol umbi bawang dayak sedikit demi sedikit lalu digerus hingga homogen. 


\section{Evaluasi fisik Masker Gel Peel Off}

\section{a. Uji Organoleptis}

Uji organoleptis dilakukan dengan melihat warna, mencium bau, dan tekstur dari gel alami yang dibuat (Ansel, 1989). Dilakukan 3 kali replikasi dengan 6 orang relawan (Depkes RI, 2011).

b.Pengujian $\mathrm{pH}$

$\mathrm{pH}$ menggunakan kertas $\mathrm{pH}$, dengan ditimbang 1 gram sediaan yang telah ditambahkan aquadest, dicelupkan kertas $\mathrm{pH}$ kedalam sediaan, kemudian ditunggu hasil yang didapat disesuaikan dengan angka $\mathrm{pH}$. Hasil pembacaan yang stabil merupakan $\mathrm{pH}$ gel tersebut, yang diharapkan sama dengan $\mathrm{pH}$ kulit yaitu 4,5-6,5 (Anief, 1997).

c.Pengujian Viskositas

Pengujian viskositas dengan menggunakan viskometer VT-04E dilakukan dengan menempatkan sejumlah sampel dalam viskometer. Ukuran spindle dan kecepatan putaran yang akan digunakan diatur, dan selanjutnya alat dinyalkan, dan viskositas dari masker gel peel off akan terbaca (Septiani dkk. 2011). Nilai viskositas sediaan gel yang baik yaitu 20004000centi poins (Garg dkk., 2002). Pengujian viskositas dilakukan 3 kali replikasi.

d.Pengujian Daya Sebar

Dengan cara sejumlah 1 gram ekstrak diletakkan diatas kaca yang berskala, kemudian bagian atasnya diberi kaca yang sama, dan ditingkatkan bebannya dengan menggunakan anak timbangan $50 \mathrm{~g}$, dan $100 \mathrm{~g}$ dan diberi rentangwaktu 1 menit. Kemudian diameter penyebaran diukur pada setiap penambahan beban pada saat sediaan berhenti menyebar dengan menggunakan jangka sorong. Daya sebar 5-7 cm menunjukkan onsistensi semi solid yang sangat nyaman dalam penggunaan (Arista dkk., 2013). Dilakukan 3 kali replikasi.

e.Pengujian Waktu Sediaan Mengering

Pengujian waktu kering dilakukan dengn cara mengoleskan masker gel berbagai konsentrasi kepunggung tangan dan diamati waktu yang diperlukan sediaan untuk mengering, yaitu waktu dari saat mulai dioleskan masker gel hinga benar-benar terbentuk lapisan yang kering. Kemudian waktu tersebut dibandingkan dengan waktu kering masker produk inovator yang beredar dipasaran yaitu sekitar 10-20 menit (Vieira dkk., 2009). Dilakukan 3 kali replikasi.

\section{f. Uji Homogenitas}

Pengujian homogenitas dilakukan dengan cara sampel gel dioleskan pada sekeping kaca atau bahan transparan lain yang cocok, sediaan harus menunjukkan susunan yang homogen dan tidak terlihat adanya butiran kasar (Depkes, 1979).

\section{ANALISIS DATA}

Data hasil penelitian dianalisis dengan program SPSS dengan metode independent sampel $T$ test. di sajikan dalam bentuk table dan diagram batang kemudian dinarasikan.

\section{Hasil dan Pembahasan}

Uji organoleptis merupakan uji parameter fisik ntuk melihat perubahan bentuk/tekstur, warna dan bau, uji organoleptis dilakukan dengan melihat warna, mencium bau,dan melihat bentuk/tekstur dari gel alami yang dibuat (Ansel, 1989). Hasil pengujian organoleptis gel peel off dari ekstrak umbi bawang dayak dapat dilihat pada tabel II. 
Tabel II. Uji Organoleptis Masker Gel Peel Off dari Ekstrak Etanol Umbi Bawang Dayak

\begin{tabular}{cclll}
\hline Formula Gel & Replikasi & Bau & Warna & Tekstur \\
\hline \multirow{2}{*}{1} & 1 & Khas mawar & Coklat & Lembut \\
& 2 & Khas mawar & Coklat & Lembut \\
& 3 & Khas mawar & Coklat & Lembut \\
\hline \multirow{2}{*}{2} & 1 & Khas mawar & Coklat & Lembut \\
& 2 & Khas mawar & Coklat & Lembut \\
& 3 & Khas mawar & Coklat & Lembut \\
\hline \multirow{2}{*}{3} & 1 & Khas mawar & Coklat & Lembut \\
& 2 & Khas mawar & Coklat & Lembut \\
& 3 & Khas mawar & Coklat & Lembut \\
\hline
\end{tabular}

Berdasarkan hasil pengamatan pada tabel II diketahui bahwa formula 1,2 dan 3 memiliki warna, tekstur, dan bau yang sama. Bau pada sediaan masker gel peel off dihasilkan dari bau minyak mawar. Warna coklat pada gel dihasilkan dari zat aktif umbi bawang dayak, dan tekstur yang dihasilkan dari sediaan masker gel peel off ini lembut. Selanjutnya dilakukan evaluasi viskositas. Dimana pengujian viskositas merupakan faktor yang penting karena mempengaruhi parameter daya sebar dan zat aktif dari sediaan masker gel tersebut. Selain itu, gel yang memiliki viskositas optimum akan mampu menahan zat aktif tetap terdispersi dalam basis gel dan meningkatkan konsistensi gel tersebut (Madan \& Singh, 2010).

Nilai viskoitas sediaan masker gel peel off yang baik yaitu 2000-4000cp (Garg dkk,2002). Uji viskositas dilakukan dengan menggunakan viskometer VT-04E. Hasil pengamatan untuk pengujian viskositas gel dapat dilihat pada tabel III dan gambar 1 .

Tabel III. Uji Viskositas Masker Gel Peel Off dari Ekstrak Etanol Umbi Bawang Dayak

\begin{tabular}{cccc}
\hline Formula & $\begin{array}{c}\text { Replikasi sediaan } \\
\text { masker gel Peel off }\end{array}$ & $\begin{array}{c}\text { Viskositas } \\
(\mathbf{c p s})\end{array}$ & Rata-rata \pm SD \\
\hline \multirow{2}{*}{1} & 1 & 2.100 & \\
& 2 & 2.600 & $2.400 \pm 0.26$ \\
3 & 2.500 & \\
\multirow{2}{*}{2} & 1 & 2.800 & \\
& 2 & 3.000 & \\
& 3 & 3.400 & \\
\multirow{2}{*}{3} & 1 & 3.600 & \\
& 2 & 3.900 & \\
& 3 & 4.000 & \\
\end{tabular}

Formulasi masker gel peel off dari ekstrak etanol umbi bawang dayak (eleutherinebulbosa (mill.) Urb. Eleutherine americana merr) (Dian Kartikasari) 


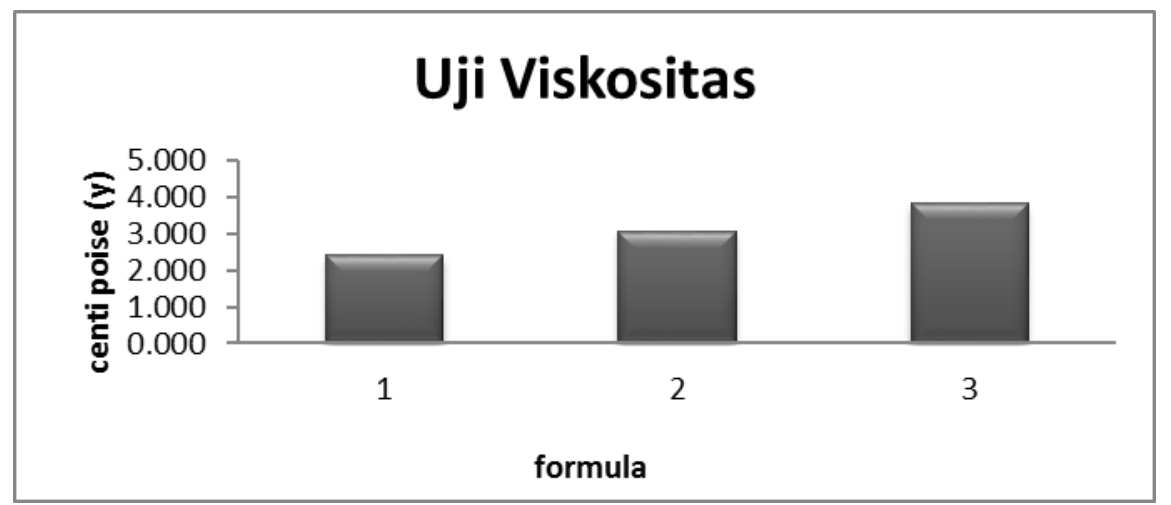

Gambar 1. Uji Viskositas Masker Gel Peel Off Ekstrak Etanol Umbi Bawang Dayak

Dari hasil pengujian diatas dapat didapat hasil viskositas formula 1 dengan rata-rata 2.400 \pm 0.26 , formula 2 dengan rata-rata $3.066 \pm 0.31$ dan formula 3 dengan rata-rata $3.833 \pm 0.21$. Dari semua formula nilai viskositas yang tertinggi didapat pada formula 3 dengan konsentrasi PVA $13 \%$ dan nilai viskositas terendah terdapat pada formula 1 dengan konsentrasi PVA $10 \%$. untuk itu dapat disimpulkan bahwa semakin tinggi konsentrasi PVA sebagai pembentuk film maka nilai viskositas semakin meningkat. Hal tersebut disebabkan karena penambahan propilenglikol sebagai agen penstabil dapat digunakan untuk meningkatkan viskositas masker gel peel off . Dilakukan uji viskositas untuk mampu menggambarkan tahan dari suatu sediaan untuk mengalir. Semakin besar tahanannya maka semakin besar viskositasnya. Semakin tinggi viskositas suatu bahan, maka bahan tersebut akan memiliki kecenderungan semakin baik karena pergerakan partikel akan menjadi sulit dengan makin kentalnya suatu bahan.

Pengaruh penambahan konsentrasi suatu bahan pada setiap formula akan berpengaruh terhadap respon viskositas, maka dari itu dilakukan analisis data menggunakan SPSS dengan metode independent sampel $T$ test. Berdasarkan hasil yang didapat dari pengujian independent sampel $T$ test $t$ menunjukkan formula 1 dan formula 2 nilai signifikansi 0.04 kurang dari 0,05 yang artinya datanya berbeda bermakna, formula 2 dan formula 3 nilai sigfikansi 0,02 kurang dari 0,05 yang artinya data berbeda bermakna, sedangkan pada formula 1 dan formula 3 nilai signifikansi 0,00 kurang dari 0,05 yang artinya data berbeda bermakna untuk semua formula dapat ditarik kesimpulan bahwa formula 1, 2 dan 3 nilai signifikansi kurang dari 0,05 dapat dikatakan bahwa penambahan PVA berpengaruh terhadap respon peningkatan viskositas yang mana semakin meningkatnya nilai viskositas maka daya sebar menurun.

Pada pengujian $\mathrm{pH}$ dilakukan untuk melihat sediaan aman atau tidak untuk digunakan pada kulit. Hasil pengujian $\mathrm{pH}$ masker gel peel off dari ekstrak etanol umbi bawang dayak dapat dilihat pada tabel IV dan gambar 2.

Tabel IV. Uji pH Masker Gel Peel Off Ekstrak Etanol Umbi Bawang Dayak

\begin{tabular}{cccc}
\hline Formula & Replikasi & Hasil $\mathbf{~ H}$ & Rata-rata \\
\hline 1 & 1 & 7 & 7 \\
& 2 & 7 & \\
3 & 7 & 6 \\
2 & 1 & 6 & \\
& 2 & 6 & 6 \\
\hline \multirow{2}{*}{3} & 3 & 6 & \\
& 1 & 6 & \\
& 2 & 6 & \\
\hline
\end{tabular}

JIFFK Vol. 14, No. 1, JUNI 2018, Hal. 01 - 11 


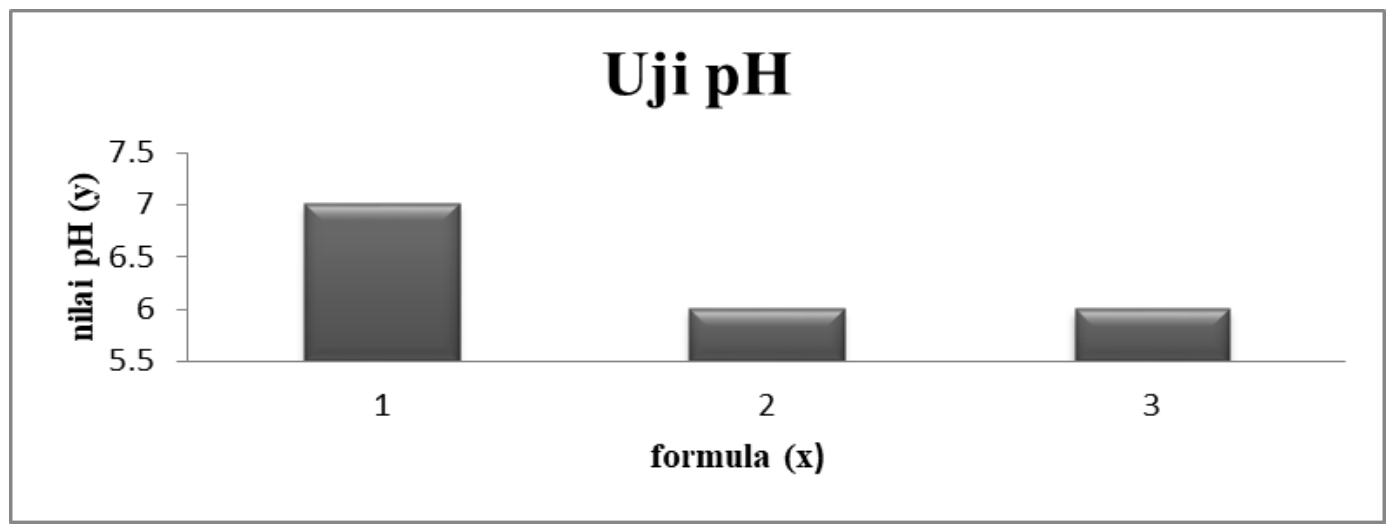

Gambar 2. Uji pH Masker Gel Peel Off Ekstrak Etanol Umbi Bawang Dayak

Berdasarkan hasil pengamatan pada tabel IV dan gambar 2 diketahui bahwa $\mathrm{pH}$ sediaan yang didapat pada formulasi 1 yang memiliki $\mathrm{pH} 7$ dapat dikatakan $\mathrm{pH}$ netral yang artinya masih aman digunakan. Pada formulasi 2 dan 3 memiliki pH 6 yang artinya sama dengan $\mathrm{pH}$ kulit wajah yaitu 4,5-6,5 (Anief, 1997) dapat disimpulkan bahwa pada formulasi 1, 2 dan 3 baik digunakan pada masker gel peel off.

Tabel V. Uji waktu sediaan mengering Masker Gel Peel Off Ekstrak Etanol Umbi Bawang Dayak

\begin{tabular}{cccc}
\hline Formula & Replikasi & Waktu Sediaan Mengering (menit) & Rata-rata (menit) \\
\hline \multirow{2}{*}{1} & 1 & 19 & \\
& 2 & 16 & 17.33 \\
\hline \multirow{2}{*}{2} & 3 & 17 & \\
& 1 & 15 & 16.33 \\
& 2 & 18 & 15 \\
3 & 3 & 16 & \\
& 1 & 14 & \\
\hline
\end{tabular}

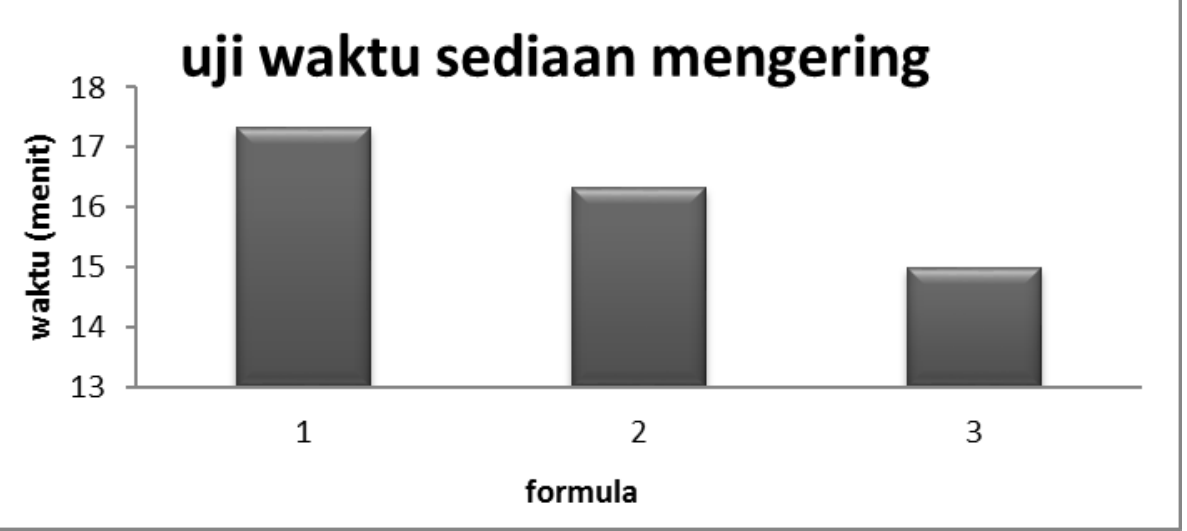

Gambar 3. Uji waktu sediaan mengering Masker Gel Peel Off Ekstrak Etanol Umbi Bawang Dayak 
Pengujian waktu sediaan mengering dilakukan dengan mengamati pada menit keberapa yang diperlukan sediaan mengering. Waktu yang digunakan untuk sediaan gel mengering yang baik yaitu 10 sampai 20 menit (Vieire dkk., 2009). Jika sediaan masker gel peel off cepat mengering dapat dikatakan sediaan tersebut sangat baik untuk digunakan karena dalam pengaplikasian tidak membutuhkan waktu yang lama untuk berefek, sedangkan jika sediaan mengering dalam waktu lama maka sediaan juga membutuhkan waktu yang lama untuk berefek sehingga terkadang menimbulkan rasa yang tidak nyaman saat pemakaian.

Berdasarkan hasil pengamatan pada tabel 5 dan gambar 3 pada formula 1 memiliki waktu yang lebih lama untuk mengering yaitu 17,33 menit, dibandingkan dengan formula 2 dan 3 . Pada formula 2 membutuhkan waktu mengering selama 16.33 menit dan pada formula 3 memiliki waktu mengering yaitu 15 menit. Ada formla 3 memiliki waktu mengering yang lebih baik, karena konsentrai PVA pada formula 3 yang digunakan lebih besar yaitu $13 \%$ dibandingkan dengan formula 1 yaitu $10 \%$ dan formula 2 yaitu $12 \%$. Ciri-ciri jika sediaan sudah mengering adalah tampak jelas pada sediaan yang telah dioleskan pada daerah kulit wajah mengalami pengeringan. Berdasarkan hasil yang didapat dari pengujian independent sampel $T$ test $t$ menunjukkan formula 1 dan formula 2 nilai signifikansi 0,46 lebih dari 0,05 yang artinya data tidak berbeda bermakna, formula 2 dan formula 3 nilai signifikansi 0,27 kurang dari 0,05 yang artinya data berbeda bermakna, formula 1 dan formula 3 nilai signifikansi 0,09 lebih dari 0,05 yang artinya data tidak berbeda bermakna, untuk semua formula dapat ditarik kesimpulan bahwa formula 1 dan 3 nilai signifikansi lebih besar dari 0,05 dapat dikatakan bahwa penambahan PVA berpengaruh terhadap respon peningkatan waktu mengering yang mana semakin meningkatnya nilai PVA maka suatu sediaan akan mudah mengering.

Parameter lain yang digunakan untuk menguji sifat fisik gel adalah pengujian Homogenitas. Pengujian Homogenitas ini dilakukan untuk melihat apakah bahan-bahan yang digunakan dalam pembuatan sudah tercampur sempurna atau belum.

Tabel VI. Uji Homogenitas Masker Gel Peel Off Ekstrak Etanol Umbi Bawang Dayak

\begin{tabular}{cccc}
\hline Formula & Replikasi & Hasil & Kesimpulan \\
\hline \multirow{2}{*}{1} & 1 & Tidak terdapat gumpalan & \\
& 2 & Tidak terdapat gumpalan & Homogen \\
& 3 & Tidak terdapat gumpalan & \\
\hline \multirow{2}{*}{2} & 1 & Tidak terdapat gumpalan & \\
& 2 & Tidak terdapat gumpalan & Homogen \\
3 & 1 & Tidak terdapat gumpalan & \\
\hline & 2 & Tidak terdapat gumpalan & \multirow{2}{*}{ Homogen } \\
& 3 & Tidak terdapat gumpalan & \\
\hline
\end{tabular}

Homogenitas dalam sediaan akan berpengaruh pada penyebaran gel di kulit, jika gel tersebut sempurna maka efek yang dihasilkan akan maksimal. Gel harus memiliki masa yang homogen. Tidak boleh adanya bahan padat yang masih mengumpal pada saat dioleskan akan berpengaruh pada zat aktif yang diserap.

Dari hasil tabel VI diatas pada formula 1, 2 dan 3 dapat dilihat bahwa sediaan masker gel peel off dari ekstrak etanol umbi bawang dayak merupakan sediaan yang homogen karena tidak terdapat gumpalan atau partikel kasar pada sediaan. Pada formula 1, 2 dan 3 tidak mengalami perubahan signifikan. Jadi, dapat disimpulkan pada formula 1, 2 dan 3 merupakan sediaan masker gel peel off yang baik untuk digunakan. Pada pengujian ini menunjukkan kemampuan penyebaran masker gel peel off dari ekstrak etanol umbi bawang dayak, pada kulit saat dioleskan. Hasil pengamatan untuk pengujian daya sebar gel dapat dilihat pada tabel VII.

JIFFK Vol. 14, No. 1, JUNI 2018, Hal. 01 - 11 
Tabel VII. Uji Daya Sebar Masker Gel Peel Off Ekstrak Etanol Umbi Bawang Dayak

\begin{tabular}{cccc}
\hline Formula & Beban (gram) & $\begin{array}{c}\text { Diameter Daya } \\
\text { Sebar }(\mathbf{c m})\end{array}$ & $\begin{array}{c}\text { Rata-rata Diameter } \\
\text { Daya Sebar (cm) }\end{array}$ \\
\hline \multirow{3}{*}{1} & 0 & 2,74 & \\
& 50 & 6,09 & 5,49 \\
& 100 & 6,43 & \\
2 & 150 & 6,70 & 4,90 \\
& 0 & 2,33 & \\
& 50 & 4,95 & 4,71 \\
3 & 100 & 6,02 & \\
& 150 & 6,29 & \\
& 0 & 2,39 & \\
& 50 & 4,82 & \\
& 100 & 5,80 & \\
\hline
\end{tabular}

Berdasarkan hasil pengujian daya sebar masker gel menunjukan bahwa daya sebar bertambah dengan bertambahnya berat beban terhadap sediaan masker gel, maka semakin luas penyebaran masker gel yang terbentuk. Viskositas suatu sediaan berpengaruh pada luas penyebarannya. Semakin kecil viskositas suatu sediaan maka penyebarannya akan semakin besar. Dapat disimpulkan dari semua formula bahwa gel menunjukan daya sebar yang baik. Daya sebar berkaitan dengan dengan sifat penyebaran gel peel off ketika digunakan pada sediaan topikal. Semakin besar daya sebar, luas permukaan kulit yang kontak dengan gel akan semakin luas dan zat aktif akan terdistribusi dengan baik. Gel yang memiliki daya sebar yang besar sehingga dapat diaplikasikan pada permukaan kulit yang luas tanpa penekanan yang berlebihan.

Tabel VIII. Hasil Evaluasi Fisik Gel Peel Off Ekstrak Umbi Bawang Dayak

\begin{tabular}{cccccc}
\hline Formula & $\mathrm{pH}$ & Homogenitas & $\begin{array}{c}\text { Daya } \\
\text { Sebar }\end{array}$ & Viskositas & Waktu Mengering \\
\hline 1 & 7 & Homogen & 6.7 & $2.400 \mathrm{cp}$ & 17.33 \\
2 & 6 & Homogen & 6.29 & $3.066 \mathrm{cp}$ & 16.33 \\
3 & 6 & Homogen & 5.815 & $3.833 \mathrm{cp}$ & 15
\end{tabular}

Pengaruh penambahan konsentrasi suatu bahan pada setiap formula akan berpengaruh terhadap respon daya sebar, maka dari itu dilakukan analisis data menggunakan program SPSS dengan metode independent sampel $\mathrm{T}$ test. Formula 1 dan formula 2 nilai signifikansi 0,66 lebih dari 0,05 yang artinya tidak berbeda bermakna, formula 2 dan formula 3 nilai signifikansi 0,88 lebih dari 0,05 yang artinya tidak berbeda bermakna, formula 1 dan 3 nilai signifikansi 0,54 lebih dari 0,05 yang artinya tidak berbeda bermakna, dan untuk semua formula dapat ditarik kesimpulan bahwa formula 1, 2 dan 3 memiliki nilai signifikansi lebih dari 0,05dapat dikatakan bahwa penambahan PVA berpengaruh terhadap respon peningkatan viskositas yang mana semakin meningkatnya nilai viskositas maka daya sebar menurun.Dari data evaluasi fisik diatas dapat dilihat pada uji $\mathrm{pH}$ formulasi 1 berbeda dengan $\mathrm{pH}$ formulasi 2 dan 3, formulasi 1 memiliki $\mathrm{pH} 7$ dapat dikatakan $\mathrm{pH}$ netral yang dikatakan $\mathrm{pH}$ yang aman digunakan. Dilihat pada formulasi 2 dan 3 memiliki pH yang sama yaitu 6 sehingga masuk kedalam pH kulit wajah 4,5-6,5 (Anief,1997). Uji homogenitas pada formula 1,2 dan 3 dikatakan semua sediaannya homogen tidak ada partikel 
kasar dan gumpalan pada sediaan. Pada pengujian daya sebar dengan menggunakan SPSS, pada uji independent sampel $T$ test formula 1 dan 2 memiliki nilai signifikansi 0,66 , formula 2 dan 3 memiliki nilai signifikansi0,88, formula 1 dan 3 memiliki nilai signifikansi 0,54 . Dari formula 1,2 dan 3 dapat disimpulkan bahwa nilai signifikansi lebih dari 0,05 yang artinya tidak berbeda bermakna, jadi dapat dikatakan formula 1, 2 dan 3 tidak memiliki perbedaan yang signifikan.

Pengujian viskositas dengan uji independent sampel T test diketahui nilai signifikansi formula 1 dan 2 memiliki nilai signifikansi 0,04, formula 2 dan 3 nilai signifikansi 0,02 , formula 1 dan 3 nilai signifikansi 0,00. Dari formula 1,2 dan 3 dapat disimpulkan bahwa nilai signifikansi kurang dari 0,05 yang artinya data berbeda bermakna. Pengujian waktu sediaan mengering dengan uji independent sampel $T$ testformula 1 dan 2 memiliki nilai signifikansi 0,46 , formula 2 dan 3 memiliki nilai signifikansi 0,27 formula 1 dan 3 memiliki nilai siignifikansi 0,09. Dapat disimpulkan bahwa formula 1 dan 3 memiliki nilai signifikansi lebih dari 0,05 yang artinya data tersebut tidak berbeda bermakna, sedangkan pada formula 2 nilai signifikansi kurang dari 0,05 yang artinya data tersebut berbeda bermakna.

Dari tabel 8 diatas dapat dikatakan bahwa pada formula 3 dengan konsentrasi PVA 13\% dikatakan sediaan yang baik karena dilihat dari uji $\mathrm{pH}$, daya sebar, viskositas, homogenitas dan waktu sediaan mengering termasuk sediaan yang baik.

\section{KESIMPULAN}

Sediaan masker gel peel off yang baik dari ketiga formula adalah formula 3 dengan konsentrasi PVA 13\%, yang memiliki hasil evaluasi yang memenuhi persyaratan uji yaitu hasil uji organoleptis yaitu berbau khas mawar, berwarna coklat dan memiliki terkstur lembut. uji homogenitas yang memiliki hasil homogen, uji viskositas dengan hasil $3.833 \mathrm{cps}$, uji $\mathrm{pH}$ yang menghasilkan $\mathrm{pH}$ sesuai standar $\mathrm{pH}$ kulit wajah yaitu 6, uji waktu sediaan mengering kurang dari 15 menit, dan uji daya sebar yaitu $5.815 \mathrm{~cm}$.

\section{UCAPAN TERIMA KASIH}

Penulis ucapkan terima kasih kepada Akademi farmasi Yarsi Pontianak atas dukungan selama penulis melakukan penelitian

\section{DAFTAR PUSTAKA}

Ansel, C, Howard, 1989, Pengantar Bentuk Sediaan Farmasi, Edisi Keempat, Jakarta Universitas Indonesia Pres, 162-163; 390-391; 605-608

Barel, A. O., M. Paye, and H.I Maibach. 2009, Handbook of Cosmetic Science and Technology. New York: Informa Healthcare USA, Inc.

Beringhs, A.O., M.R. Julia, K.S. Hellen, M.B. Rosane, and S. Diva. 2013. Green clay and aloe vera peel-off facial masks: response surface methodology applied to the formulation design. AAPS Pharm Sci Tech. 14 (1): 445-455.

Birck, C., S. Degoutin, N. Tabary, V. Miri, and M. Bacquet, 2014, New crosslinked cast films based on poly (vinyl alcohol): preparation and physico-chemical properties. Express Polymer Letters. 8 (12): 941-952

Depkes RI, 1979, Farmakope Indonesia, Edisi III, Departemen Kesehatan Republik Indonesia, Jakarta, 378; 353; 596

JIFFK Vol. 14, No. 1, JUNI 2018, Hal. 01 - 11 
Draelos, Z.D., and L.A. Thaman. 2006, Cosmetic Formulation of Skin Care Product, Taylor \& Francis Group, New York.

Galingging, R. Y. (2009), Bawang Dayak (Eleutherine palmifolia) Sebagai Tanaman Obat Multifungsi. Warta Penelitian dan Pengembangan Vol 15, No 3, 2-4.

Garg. A., D. Aggarwal, S. Garg, dan A. K. Sigla. 2002. Spreading of Semisolid Formulation. USA : Pharmaceutical Technology, 84-104

Grace, F.X., C. Darsika, K.V. Sowmya, K. Suganya, and S. Shanmuganathan, 2015, Preparation and Evaluation of Herbal Peel Off Face Mask. American Journal of PharmTech Research. (5): 33-336.

Hidayah, S.A., K. Mulkiya, dan L. Purwanti, 2015, Uji Antioksidan Umbi Bawang Dayak (Eluetherinebulbosa Merr.), Skripsi, Universitas Islam Bandung. 397-403.

Madan, J., and R. Singh, 2010, Formulation and Evaluation of Aloevera Topical Gel. Int J.Ph.Sci. 2 (2): 551-555.

Rahmawanty, Dina., Nita. Yulianti, dan Mia. Fitriana, 2015, Formulasi dan Evaluasi Masker Wajah Peel-Off Mengandung Kuersetin Dengan Variasi Konsentrasi Gelatin dan Gliserin."Media Farmasi. 12 (1): 17-32.

Septiani, S, N. Wathoni, dan S.R. Mita, 2011, Formulasi Sediaan Masker Gel Antioksidan dari Ekstrak Etanol Biji Melinjo (Gnetum Gnemon Linn), Jurnal Unpad I(I) 4-24.

Velasco, M.V.R.., Vieira R.P., Fernandes A.R., Dario M.F., Pinto C.A.S.O., Pedriali C.A., Kaneko T.M., and Baby A.R., 2014, Short-term clinical of peel-off facial mask moisturizers. International Journal of Cosmetic Science, 36: 355-360.

Vieira, R.P, 2009, Physical and Physicochemical Stability Evaluation of Cosmetic Formulations Containing Soybean Extract Fermented by Bifidobacterium animalis, Brazilian Journal of Pharmaceutical Sciences, 45(3): 515-525

Yeom, G., D.M. Yun, Y.W. Kang, J.S. Kwon, I.O. Kang, and S.Y, Kim, 2011, Clinical efficacy of facial masks containing yoghurt and Opuntia humifusa Raf. (F-YOP). J. cosmet Sci. 62 (5): 505-514.

Zague, V., M.R. Velasco, and A.R. Baby, 2008, Mascaras faciais, Sao Paulo: Livraria Santa Isabel. 